\title{
THE MOST CONTESTED IN FINLAND: LARGE CARNIVORES AND THE SAIMAA RINGED SEAL - CHALLENGES OF SOCIO-ECOLOGICAL RHYTHMS AND THEIR PRACTICAL IMPLICATIONS
}

\author{
Outi Ratamäki ${ }^{1}$, Pekka Salmi ${ }^{2}$
}

Received 23 May 2014; Accepted 25 February 2015

\begin{abstract}
This article illustrates two Finnish case studies: one about large carnivores and the other about the protection of the Saimaa ringed seal. These cases are analysed by using the concept of life-mode introduced by Thomas Højrup and rhythm analysis developed by Henry Lefebvre. The objective of the paper is to show how the connection between life-modes and spatial and temporal rhythms of humananimal interactions help to better understand the contradictions and conservation challenges of these species. The introduction of new practices, e.g. a new enterprise or conservation of an endangered species, creates arrhythmias to more traditional practices which can be very resistant to change. This resistance is because maintaining rhythms is also to uphold one's life-modes and associated identities. Life-modes are expressed and regenerated by different practices, symbols and concepts in time and space.
\end{abstract}

Keywords: rhythmanalysis, rhythms, life-mode, large carnivores, Saimaa ringed seal, wildlife conservation

\begin{abstract}
Abstrakti: Tämä artikkeli käsittelee saimaannorppaan ja suurpetoihin liittyviä suojeluhaasteita. Analyysivälineinä on käytetty Thomas Højrupin elämänmuodon ja Henry Lefebvren rytmin käsitteitä. Näiden käsitteiden avulla kuvataan inmisten ja eläinten välisen vuorovaikutuksen ilmentymistä ajassa ja tilassa. Analyysin avulla osoitetaan, kuinka erilaisia elämänmuotoja pidetään yllä rytmittyneillä käytännöillä, ja kuinka nämä rytmittyneet käytännöt ovat tapa ilmaista kulttuuria ja identiteettiä. Modernit tai uudet toimimisen tavat, kuten suurpetoturismi, tai poliittiset tavoitteet, kuten uhanalaisten lajien suojelu, aiheuttavat rytmihäiriöitä haastamalla perinteiset sosiaaliset ja materiaaliset rytmit. Ymmärrys rytmien kytkeytyneisyydestä elämänmuotoihin auttaa ymmärtämään myös konfliktien perimmäisiä syitä.
\end{abstract}

\footnotetext{
${ }^{1}$ Dr. Outi Ratamäki, Philosophical Faculty, School of Humanities, University of Eastern Finland, Joensuu, Finland and Environmental Policy Centre, Environmental Governance Studies Unit, Finnish Environment Institute (SYKE), Joensuu, Finland, P. O. Box 111, FI-80101 Joensuu, FINLAND, email. outi.ratamaki@uef.fi

2 Dr. Pekka Salmi, Finnish Game and Fisheries Research, Itäinen Pitkäkatu 3, FI-20520 Turku, FINLAND, email: pekka.salmi@rktl.fi
} 


\section{Introduction}

Animals have traditionally been invisible in sociological studies, while having a significant role in rural ways of life (Tovey, 2003). Lately, however, as animals - wild animals in particular - are re-introduced to rural areas, their social and cultural meaning has evoked researchers' interest (Buller, 2004). This article examines human-animal contradictions by using the concepts of lifemodes and rhythms. We illustrate two case studies: one about large carnivores and the other about the protection of the Saimaa ringed seal. Both cases are from Finland. Large carnivores, especially the wolf and bear, and the Saimaa ringed seal are iconic species for nature conservation in Finland. Attitudes towards these species have markedly changed over time. At present, both are highly contested, since the populations are low and thus conservation efforts have become increasingly strict (Bisi et al, 2007; Ratamäki, 2013a). The species protection measures have challenged traditional and culturally valued practices of natural resource utilisation: hunting and fishing (Bisi et al, 2010). Wolves kill hunting dogs, fear of bears may restrain people from berry picking and hiking, and fishing practices have faced new restrictions because of the protection of the Saimaa ringed seal.

In addition to the recreational use of natural resources, farming and commercial fishing have also faced problems over these species. Wolves attack livestock and reindeer, bears destroy beehives and seasonal fishing restrictions reduce livelihood opportunities. Lake areas are normally used by both fishers and the ringed seals in harmony, but in the springtime in particular, some newly-weaned pups have accidentally drowned in the gill nets.

The large carnivore and ringed seal interactions are entangled with human-human contradictions, which reflect diverse tensions ranging from the ideas of local self-determination to the international harmonisation of biodiversity conservation. We will analyse the different lifemodes present in the case studies and explore how the contradictions are produced by the spatial and temporal rhythms of the animal and human activities. Our research question is: how does looking at the life-modes and spatial and temporal rhythms of human-animal interactions help us to better understand the contradictions and conservation challenges of these species?

\section{Conceptualising life-modes and rhythms}

We will start our analysis with Thomas Højrup's (2003) notion of a life-mode. According to Højrup (2003: 4) the study of cultural differences and contradictions takes its point of departure in a society containing distinct life-modes, each of which creates its own mode of existence and universe of concepts.

"The logic of a life-mode lies in the structural problematics by which subjects perceive 'the environment' in the activities of praxis; when subjects disagree about what the world looks like, it is because they operate with different conceptual systems which blind them to each other's ways of seeing" (Højrup 2003: 5).

From the perspective of action-oriented ethnology introduced by Højrup, everyday life contains a paradox: society consists of several forms of praxis, each with their own respective problematics, but members of society are blind to these contrasts. One example of this is how the same words are used with quite different cultural meanings, which reflect the differences in life-modes (Højrup 2003: 5). This cultural context-dependence in the use of concepts is also challenging to research.

Højrup's life-mode concept has been accused of being too static or stable (Bærenholdt, 2009). We share this concern and will thus combine the analysis of life-modes with the concept of rhythm which has been brought forth by Henri Lefebvre (2004). The concept of "life-mode" helps us to understand the differences between cultural elements of human activities, whereas the concept "rhythm" helps us to analyse the temporal and spatial realisation of these activities. In this paper we utilise Højrup's and Lefebvre's conceptual frameworks at a general level only: we study how practical interactions in space and time reflect - or are produced by - cultural differences and life-modes. 
Rhythms, defined by Lefebvre, are not merely about movement or mobility, nor about sequence of objects. These would give a rhythm a mechanical overtone. To Lefebvre, rhythms are more than this. Rhythms occur every time energy is expended at the interaction of place and time. Everything has a rhythm, nothing is stable. For example a rock or a forest has a rhythm; it is just much slower than the rhythm of the human observer. Rhythms are not only natural (neurological or biological); they are also social and therefore learned (Edensor, 2010). For example, dogs are trained to obey the rhythms of the society which they inhabit. Rhythms have both quantitative and qualitative characters. A painting's rhythm can be seen as a series of brushstrokes or a piece of art of the time, and a piece of music can be broken down into single notes or be listened to as an example of a certain musical genre. Through rhythmanalysis it is possible to see beyond individual things, images, objects or deeds and reveal them as rhythms among others (see Jones, 2010). What seems to be a fact here and now is only a flow or a stream.

To Lefebvre (1991), social space constitutes three different elements: perceived, conceived and lived spaces. This triad is analogous to other triads in Lefebvre's work (Schmid, 2008). Perceived space is material and physical and is represented by spatial practice. Perceived space is what we can see, smell or taste in a given space. Through these processes the space becomes embodied. Conceived space is mental and ideal and manifests itself through conceptualisations. These conceptualisations are often verbal representations of space. Lived space (which should not be confused with material and physical space) is social and representational, a system of non-verbal symbols and signs. These different spaces exist simultaneously and they hold a dialectic relation. They are different viewpoints of the same space. Therefore, the material and physical space, as it is sensed, is at the same time conceptualised and representative of the social. What is sensed is interpreted through what is 'known' and socially determined.

Combining Lefebvre's triadic elements with the conceptualisation of a life-mode means that society constitutes separate life-modes which all have their own system of perceived, conceived and lived spaces. The results of our case studies are analysed by making a rough distinction between life-modes and the ideas they carry regarding the use of natural resources and biodiversity conservation. We will let the rhythmanalysis guide our exploration through the data and we will take note of both social and ecological rhythms. In addition to the life-modes of humans in society, we also consider the activities and rhythms of animals in terms of a "lifemode", as animal species carry their specific patterns of spatial and temporal behaviour (Edensor, 2010).

We discuss whether focusing on the spatial and temporal rhythms of human-animal interactions could help in overcoming the blindness between life-modes and in finding common ground.

\section{Data and methods}

A rhythmanalyst is an observer, an empiricist. An analyst can (and should, according to Lefebvre) use all of his senses when identifying rhythms. Rhythms come with voices and scents (e.g. early morning turning into a late night and back again). In our analysis we will not apply such an intensive approach - our methodology is based on qualitative and ethnographic design. We have carried out interviews and observations of two empirical cases. These cases present good examples of Finnish wildlife controversies and the multidimensional data allows an analysis from the rhythm perspective.

The research data for the large carnivore case in this article is based on one case study; it is about an entrepreneur who organises photography of bears and wolverines from a hide in North Karelia, Finland. The entrepreneur has been interviewed in the very surroundings of his business. After the interview it was possible to exchange emails and check some further details. His place was also visited one other time, prior to the interview. At this time the entrepreneur did not now that the visitor was a researcher. With this three-dimensional approach (i.e. interview, emails and observations) it was possible to gather information using an open and also a more focused approach, make observations and fill in the details. This specific enterprise was chosen because it is the only entrepreneur in this part of Finland and the business is fairly new. In its 
simplicity it is a nice, clear case to be examined. In more northern regions of Finland there are other similar enterprises but they have existed for a longer time and there are several different such entrepreneurs (MEK, 2008; Eskelinen, 2009). It would have been socially and culturally a more complex case area.

The research material for the Saimaa ringed seal analysis consists of interviews with commercial fishers and key informants, and a postal survey regarding recreational fishers. Moreover, media articles and other publications dealing with the conflict have been utilised. A total of 20 personal questionnaire-based interviews with commercial fishers were made in 2010 (Salmi, Salmi and Hirvonen, 2011) and 1015 questionnaires from recreational fishers were received in 2011 (Kolari et al, 2011). Three key informant interviews, dealing with the sealfisheries contradictions and opportunities for conflict management, were made in 2010 and 2011 in the Saimaa region. This material reflects local fishing practices and fishers' varying perceptions about the importance and consequences of seal protection and fishing restrictions, and is analysed with a particular focus on indications of life-modes and rhythms.

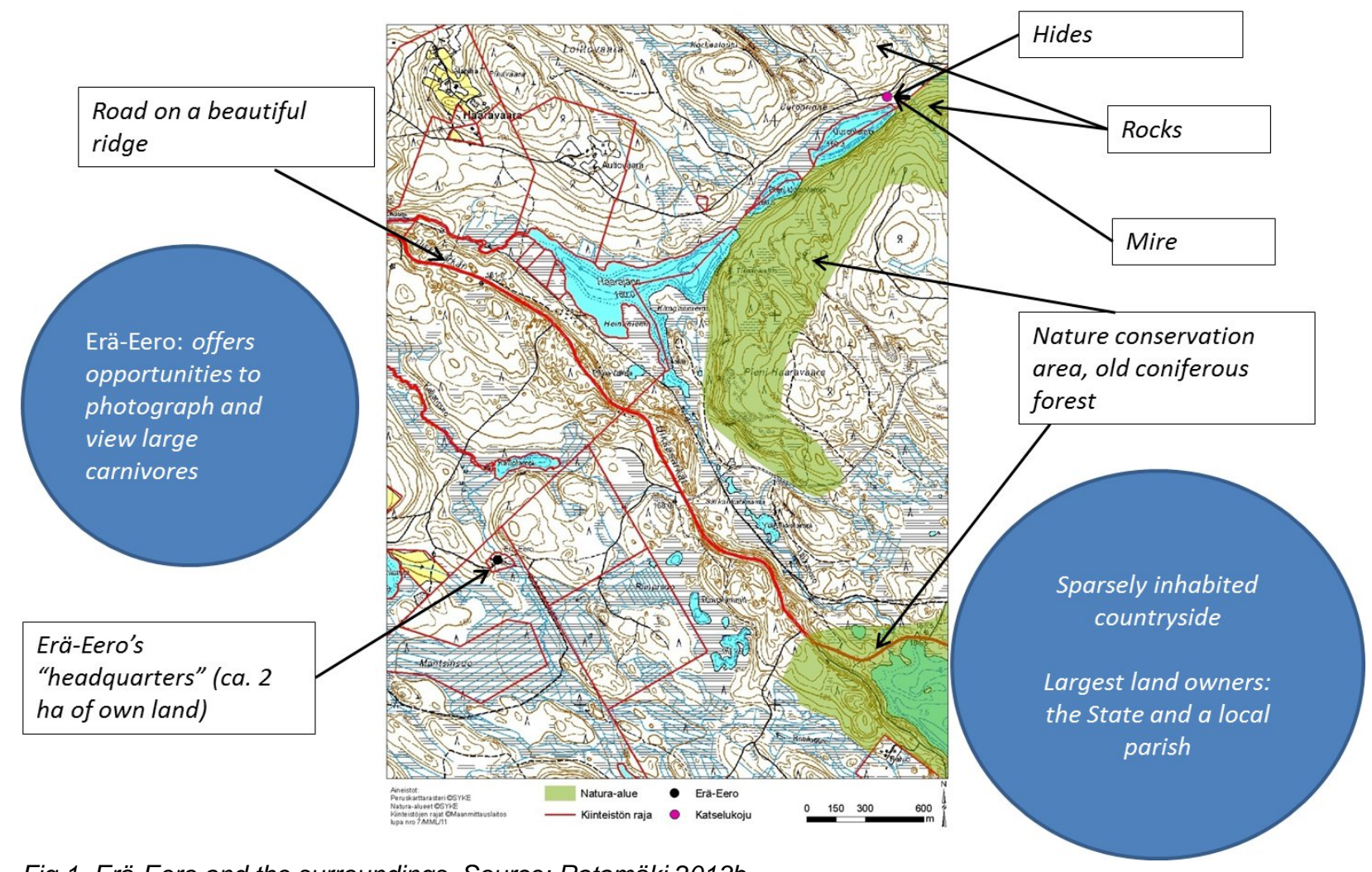

Fig 1. Erä-Eero and the surroundings. Source: Ratamäki 2013b

The life-modes and rhythms in the studied cases will be analysed and described, bearing in mind both social and ecological rhythms. Although rhythm is not really an analytical tool but only a way of looking at empirical observations, it can be very revealing. We have utilised maps in collecting the data, for example as a discussion tool in the interviews (Figure 1). This means it has been possible to discuss the spatial rhythms in the area. We have also paid attention to the temporal rhythms of the practices. These temporal rhythms can also be detected by studying the current legislation and policy documents for game management, for example. The qualitative data has been analysed using theoretically advised content analysis. Descriptions of the practices have been detected, bearing in mind their relevance for different life-modes. The data has also been "read" from the rhythmanalysis point of view. This was done by lifting to the surface all the temporal and spatial implications of the different practices, concepts and cultural symbols and signs which we heard and saw during the collection of the data or later in the reading of the textual data.

We will first focus on a description of the life-modes revealed in the data and after that we will describe the arrhythmias in the two cases. We will explore how these can be explained by the incompatibility of other life-mode dependent rhythms in the same space and time. After 
the case-based analysis, we will synthesise the results of the cases. Through this synthesis, the case study analysis will be lifted to another level, looking at the practices of human-wild animal encounters in general in Finland.

\section{Illustration of the cases}

\section{Erä-Eero}

Erä-Eero is a small private enterprise located in a remote rural area in Lieksa. Lieksa is a small town in North Karelia, Finland's easternmost province. Erä-Eero provides multiple recreational services including hiking, canoeing and rock climbing, but its speciality activity is photographing large carnivores from a hide, the wolverine (Gulo gulo) in particular. You can also spot bears (Ursus arctos) and foxes (Vulpes vulpes) and birds.

When visiting Erä-Eero it soon becomes obvious how the activities and therefore also the business is closely linked to its specific location. One drives along a beautiful sandy ridge through scenery decorated by lakes and pine forest. When reaching Erä-Eero, the traveller faces a semi-natural courtyard and old or old-looking wooden buildings. There is neither electricity nor water or a sewer system. Erä-Eero has participated in designing this location and scenery by either relocating or constructing the buildings. Here you will find a smoke sauna, huts and outdoor toilets. A river runs through the location so you can start your canoeing right on the doorstep. The main building used to serve as quarters for loggers in the early $20^{\text {th }}$ century. Now, it is the place where Eero welcomes the visitors. It is also possible to dine and overnight here. The building is classified as a heritage building and therefore has a very original atmosphere. The entrepreneur, Eero Kortelainen, owns the place and a few hectares of land around the location.

The hide itself is located a few kilometres from the "headquarters" (see Figure 1). In fact, there are several hides. One is a fairly large double-barrelled log house constructed on a slope. There are different spaces reserved for photography and sleeping. Toilet facilities are also available. Below the hide there is swamp area where the carnivores come to feed on carcasses. The landscape behind the swamp is a dense old spruce forest, part of Natura 2000. There are three other hides which are not as developed as the log house, on the right side of the swamp. These hides are at ground level for better photography angles. These constructions enable Eero to receive both professional and amateur photographers. Some visitors only want to watch. Even families with children may visit.

Eero has tried to build a network of co-operation around his business. Just recently the local hotels and other businesses related to tourism have found a shared interest with Eero. If tourists ask what they can do in the area, it is good advertisement for the region to be able to offer something as exciting as photographing large carnivores. The role of marketing his place is more and more moving from Eero to the collective of enterprises in the region. The leaders of the municipality are satisfied but Eero does not refer to any strong collaboration with them. What he would like is better co-operation with the hunters and the parish and the state as land/forest owners.

What differentiates Erä-Eero from other similar enterprises in Finland (mostly located in Kainuu, to the north of North Karelia), is the presence of wolverines. This is one of the few places in the whole world where this rare animal can be photographed. Eero has received many international visitors. There are no other enterprises of this kind in Lieksa region. However, Eero himself states that there are many unofficial and illegal carcass sites in the forests. They are not only bad for the business but also for the entire reputation of carcass-enabled photography. It is feared that keeping carcasses will familiarise the wild animals to humans. There is also the threat that animals will start combining the smell of humans with easy food (Suonpää, 2002; Pohja-Mykrä and Kurki, 2009).

Eero spends a lot of time and effort educating all the visitors about proper behaviour in the hides. You have to be very quiet, you must avoid excessive walking and whispering is the only proper way to communicate. Visitors' own food or drinks are not allowed. Long pipes from the hides deliver the scent of humans high up in the air. This is how Eero controls 
the rhythms of the customers to be more concordant with the rhythms of the wildlife. Eero places the carcasses using rubber gloves. He mostly uses fish, offal and the whole carcasses of slaughtered animals (mainly pigs, sometimes horses). Occasionally he uses elks (Alces alces). No one else other than Eero is permitted to walk in the swamp area. However, not everyone is convinced of these precautions and tensions are present about the legitimacy of Eero's business (Ratamäki, 2013b).

\section{Case of the Saimaa ringed seal}

The debate between local gill net fishing opportunities in the Saimaa lake system in Eastern Finland and the conservation of the Saimaa ringed seal (Pusa hispida saimensis) has become increasingly vocal in the Finnish media. Part of this high level of interest is explained by the important symbolic value of this animal species. The Saimaa ringed seal is important both nationally, as a symbol of Finnish nature conservation, and regionally, for the identity of the Saimaa region. The efforts in the conservation of the ringed seal have expanded, reaching the international level, and have led to tight fishing restrictions.

In the Saimaa lake area there are about 80,000 recreational fisher households, 30,000 of which use gill nets and wire traps. Most of the gill net fishers set their gear in water areas close to their home or summer house and wait for a period from a few hours to up to a week (in winter) before examining it. The type of the gill net (e.g. mesh size) and the fishing site is decided according to seasonal variations of the target fish species. The harvesting efforts have been adapted to the seasonal, especially spawning, rhythms and long-term fluctuations of the fish stocks. The fishing period also naturally depends on the time available to the fisher: the summer house dwellers fish more typically during the holiday season (June-August), while the local fishers operate more often throughout the year - also when the lakes are covered in ice.

In addition to recreational fishers there are 30 commercial fishers operating in the habitat of the Saimaa ringed seal. They typically combine several fishing methods, such as seine netting, pair trawling, gill netting and trap netting. In order to achieve a sufficient income level, the fishers have adapted different fishing methods for targeting a variety of fish species during their specific fishing seasons. The most important target species for trawling and seine netting is vendace (Coregonus albula). Half of the fishers use gill nets, especially for harvesting highly valuable pike-perch (Stizostedion lucioperca) - both in winter through the ice and in the open water season.

The Saimaa ringed seals spend 60 - 80 per cent of their life underwater, year after year within the same area. The lakes are ice-covered from November to April. In February, the seal gives birth to a pup in its lair dug into a snowdrift. The snow cave is invisible from the outside, and the only entrance to it is from the water. During their breeding season seals are sensitive to disturbance, by snowmobiling in particular. This is why the managing institution for the protection and monitoring of the Saimaa ringed seal population, Metsähallitus (2009), has recommended that snowmobilers should avoid islets and snow-covered spits in winter.

The pup is weaned around the time the lakes become free of ice in spring (Metsähallitus, 2009). Young pups learn to live independently, but as they are inexperienced there is a danger of entangling themselves in fishers' gill nets or wire traps. The availability of fish shoals may have an impact on the local movements of the seal, but generally the Saimaa lake region provides the seals with plenty of fish for food.

There are two types of fishing regulations, which aim at reducing the mortality of young and adult seals in fishing gear. Firstly, the Ministry of Agriculture and Forestry imposed restrictions on the use of specific gear types in 1999. These cover the whole Saimaa area throughout the year. Secondly, agreements about total closures of springtime gill net and trap net fishing have been made between local shareholder (water owner) associations and the authorities. The centralist restrictions incited a strong wave of local resistance before and after the decisions were enforced in 1999 (Tonder, 2005). Ten years later the conflict was further intensified when larger areas for springtime fishing closures were suggested and enforced. 


\section{Erä - culture and its modern versions as life-modes}

The enterprise Erä-Eero is run by a man called Eero Kortelainen; hence the latter part of the enterprise's name. However, the term "erä" is a tricky one for an international audience. Finnish people know very well what it means, even though its meaning may slightly differ from individual to individual. If looked up in a dictionary, the term is given the meaning "hunting". Yet "hunting" has its own word "metsästys" in Finnish. "Erä" is much more than hunting (Ilvesviita, 2005). It refers to a culture, almost like a lifestyle, at least to a certain way of being in interaction with nature.

Hunting in Finland is not a shooting culture. It is a culture which is closely tied to the general idea of erä-culture. There are strong cultural roots for the subsistence use of natural resources in Finland. Hunting is also valued as a means for game management (Toivonen, 2009). The work which hunters voluntarily do every year as game management is worth seven million euros to the state (Forsman et al, 2010). Hunters are used to thinking that taking care of the wild animal populations is their honorable task (sometimes if there are too many hunting licenses for elk, for example, they see this as an obligation) and at the same time hunting is their right, especially on their own land. Hunting as well as fishing are very typical and, to many, unquestioned elements of Finns' relationship with nature.

Utilising natural resources (game, fish, berries and mushrooms, etc.) is part of the "erä" phenomenon, but the connotation of the term refers to an honourable and sustainable use. A person with "erä" skills knows his or her way around the woods and lakes and has good survival skills. "Erä" culture is a cultural background for many hunters and their life-modes in Finland, even if more and more hunters live in cities (Toivonen, 2009). Some of the nature conservationist and animal rights advocates have claimed that this "erä-culture" does not really (or always) exist, but is only (or sometimes) a façade for the over-exploitation of natural resources and the brutal handling of game animals and fish (Tuomivaara and Purmonen, 1998; Karsikas, 2007).

Recent transitions in the utilisation of rural natural resources and rural development have been described as a shift from productivism towards post-productivism (Rannikko, 2008; Buller, 2004). This change can be seen as a historical development where the emphasis has shifted from production to a diversity of resource utilisation and protection. Utilising natural resources is strongly attached to the concept of "erä". Erä-Eero's business, while offering only nonconsumptive ways of utilising large carnivores, is considered a modern version of erä-culture by some of the stakeholders. This way, it is symbolically, and also in practice, closer to the idea of nature conservation than hunting.

Fishing, like hunting, forms a natural part of the erä-culture, which combines different outdoor activities in the forests and water areas. Many of the fishers are also hunters and users of other natural products. Along with the postproductivist development of society, the practices and motivations for fishing have become diversified towards a combination of traditional (rural) culture of natural resource utilisation and modern leisure amusement (Salmi and Ratamäki, 2011). In the past, fishing by gill nets and other methods was important for the subsistence of local inhabitants in Finland. Today, users of these types of passive fishing gear - both permanent local inhabitants and more mobile summer cottage dwellers - continue the subsistence culture, although fish catches are rarely economically important for the household. Summer cottages by the lakes form an elementary part of Finnish life-mode and a space for both treasuring consumptive fishing traditions and learning modern practices.

\section{Rhythmanalysis of the two cases}

\section{Arrythmias over utilising the large carnivores}

Hunting practices seem to be complex for Erä-Eero's activities. The hunting season for bears has traditionally started on 20 August and ends on 31 October. Hunting rights in Finland are bound to land ownership. Eero's hides are located on land owned by the parish (Eero has a lease) and on the other side of the hide the land is owned by the Finnish Forest and Park Service, part of the state. Both state and parish rent hunting licences to hunters. Hunting of bear 
is forbidden with the help of carcasses or other food-related bait. This means that Eero must stop using the carcasses at this time. Another option would be that hunting is restricted near the carcasses. Stopping the feeding altogether causes a potential problem to the wolverines, who have been accustomed to the feeding. The authorities have given permission to feed the wolverines but large carcasses for bears are forbidden.

The hunting of bear also has another effect on Eero's photographing activity. Bears are mostly hunted with dogs. Humans and dogs wandering around the area make a noise and disturb large carnivores. Cars used by the hunters also create noise. The hunting of elk is not so problematic since the elk is not lured to the site by carcasses and therefore the hunting activities do not come as close. It is at the end of August when the wolverine cubs of the summer start to wander beyond their dens. It is also the best tourist season for people living in Western Europe. Many photographers would enjoy taking pictures of these cubs, yet they may not enjoy meeting armed hunters. Eero has asked if the area close to his hides could be restricted from the hunting but neither the hunters nor the land owners have assented to his suggestion.

This description of Erä-Eero suggests many things: the business is highly dependent on many different ecosystem services, it is also place-dependent and therefore not transferable, it is one of a kind, it is a new phenomenon in the range of other nature-related activities in the area, it is a business but based on common resources, yet it is located on another landowners' land and therefore very sensitive to outside changes. At the local level the conflict is basically between two groups: a new enterprise and hunters. However, both these practices go beyond their local settings. Many of the hunters live in the cities, some of the hunters are "tourist hunters" and Eero's enterprise brings visitors to the Lieksa region from all over the world. It is not a clear-cut conflict between rural and urban.

\section{Generating arrhythmias for fishers and seals}

Fishers move actively on the lakes and encounter seals quite often. In her survey of fishers in the Saimaa region, Ahola (2010) found out that 86 per cent of respondents had seen the Saimaa ringed seal during their lifetime. Only six per cent of gill net fishers had never seen the species. The fishers had detected the seal, on average, on five days during the last six months. Ahola (2010: 56) suggests that for many fishers the encounters with seals is part of the everyday rhythm of life and this may reduce the impression of the species being as endangered, as is officially claimed. Connected with frequent seal observations, local people often claim that the size of the seal population is greater than the official estimate.

The interviewed commercial fishers see seals often or regularly during their everyday work on the lake. Fishers and seals meet usually each other during the open water fishing seasons. When fishers in winter see breathing holes in the ice, they know that seals live close by. Most of the fishers had detected an increase in the population during the last ten years and 40 per cent claimed that the behaviour of the seal has changed. The seal has come nearer and followed the movements of the fisher more closely than before: "Now when the seal hears the sound of the boat and has learned to follow it, it knows it can get lunch!" The seal eats fish from gill nets and trap nets. Fishers call trap nets "feeding machines for seals", because up to three seals have been seen eating fish from one trap net at the same time. The seal may also injure fish, which reduces their market value. "If the seal lives nearby, you should take your nets elsewhere." Some commercial fishers have stopped using trap nets as the visiting seals have made fishers' catches too uncertain for profitable fishing. Many fishers sell their products straight to consumers and have said, for instance, that it is harmful for their livelihoods to stop selling for two and a half months due to the gill net fishing closure. The majority of commercial fishers consider the increased fishing restrictions and hot debates as exaggerated.

When the Ministry of Agriculture and Forestry restricted fishing in the Natura 2000 areas of the Saimaa region (covering $1,260 \mathrm{~km}^{2}$ ) in 1999, the aim was to reduce the mortality of young and adult seals. Fishing methods, such as using fish as bait, strongly-built gill nets and fyke nets with closed cod-ends, were prohibited from April 2002. In 2006 and 2007 new pressures for the regulation of gill net fishing arose because of a declining trend in the ringed seal population, and since then the conservation pressures and contradictions have culminated in the springtime 
gill net fishing closures. There are several partly unknown reasons for the low reproduction rates of ringed seals. Seal biologists have tended to estimate that a substantial part of the unknown mortality has been created by fishing.

In 2008, the local shareholders' associations signed agreements for the total cessation of springtime (15.4 - 30.6) gill net fishing in an area which covered $518 \mathrm{~km}^{2}$, but this area became soon threefold. Until April 2011, the voluntary agreements covered 95 per cent of the conservation area, which had been set as target (Ministry of Agriculture and Forestry, 2011). A few associations had set a share of their water areas outside the agreement. The Parliament, however, decided in 2011 that the springtime gill net closure area should be consistent and thus a statute was imposed forbidding gill net fishing in those areas which lacked the agreements. Local water owners and fishers in the Saimaa lake region preferred the voluntary restrictions to the new top-down ones.

The increased need for continuity and large springtime closures was connected with new research findings by the seal biologists. They discovered that the seal pups move in substantially larger areas than had previously been assumed (Auttila, Niemi and Kunnasranta, 2010). This was discovered by following the movements of the seals by using radio transmitters. In 2010 the pups had swum distances of up to $15 \mathrm{~km}$ per day and their routes were unpredictable. The living areas of the young pups varied from 3 to $160 \mathrm{~km}^{2}$.

\section{Results - Erä-Eero}

If we look at Erä-Eero's activities as a composition of temporal and spatial rhythms, it is obvious that Eero's business is very dependent on the spatial and temporal rhythms of the large carnivores. However, he has some opportunities to influence these by controlling the feeding. Secondly, the built infrastructure combined with the spatial existence of the wolverines means that Eero's activities cannot be transferred to another location, at least not easily. Third, the hunters' rhythms are also dependent on the rhythms of the large carnivores, but this activity is not so spatially bound. Conclusions: 1) the responsibility and/or opportunity to avoid the arrhythmia through spatial changes fall to the hunters, 2) separating these two activities temporally seems impossible because the hunting of bear takes place when it is found to be ecologically suitable/sustainable and the best photography season of the wolverine cubs takes place at the same time.

The rhythms of the hunting and Eero's business have many similarities. They both have an annual rhythm, from one large carnivore generation to another. For hunters this annual rhythm is very important. They collect data about the status of the animal populations and this data is then analysed by researchers with the scientific frameworks of "sustainable use" or "favourable status" (Ministry of Agriculture and Forestry, 2005). Hunters actively involve themselves in keeping the ecological system and its rhythms stable and sustainable, as they have been informed by policy-makers (who actively follow the different rhythms of environmental policies). The annual rhythms finally form a longer temporal rhythm of the populations' regeneration. To Eero, the viable large carnivore populations are an asset, and he is engaged with the annual and longer regenerative rhythms through feeding the animals.

There is also another rhythm at present besides the game animal population and their management or regeneration - the rhythm of man and nature. Earlier it was stated that hunting has a long history in Finnish culture and therefore hunting as a practice has within it a rhythm of on old way of interacting with the nature. This is so, no matter how far the hunting practices may have changed from the hunter-gatherer or the agrarian ages. Hunters' appearance and all the visible signs (guns, dogs and outfits) bring this forth, but it is also embedded in the collective understanding of hunting. Eero's activity also holds something from this same cultural basis. His business is about admiring nature and facing the fear of wild animals. The infrastructure which serves as a background for his business tells many stories of the old Finnish "man and nature" or "erä" culture.

Photographing and hunting large carnivores may be very different practices and ways of interacting with nature, but culturally they stem, at least partly, from the same origins. Would realising this and recollecting the old traditional bases of hunting enable the hunters to be more 
acceptable to Eero's business? Paradoxically, Eero's business as a new phenomenon may be considered too modern, no matter how much his activity is based on offering tourists a piece of old traditions and involving them in historical and cultural rhythms of Finnish nature relations.

One element that causes tension between hunting and Eero's business is a question of collective resources. Bears and wolverines are not owned by anyone and in this case neither the hunters nor Eero own the land. It would seem they both stand in the same line. Who is allowed to engage themselves with these collective resources, how and why?

For the question "how", we need an answer between the legitimacy of hunting and carcassassisted photography of large carnivores. Hunting has strong collective support in Finland but lately the ethical legitimacy of it has been challenged in public debates (Ilvesviita, 2005; Karsikas, 2007; Salmi and Ratamäki, 2011). It has also been asked if the new generation growing up will prefer non-lethal ways of enjoying natural resources over hunting. On the other hand, as stated earlier, there is some doubt that using carcasses will shift the large carnivorehuman relationship in an unwanted direction if the animals get too accustomed to human presence (Suonpää, 2002). Hunting would have just the opposite effect. It would give the animals a signal to keep their distance. Third, there is a fear that using the carcasses will change the wild animals' behaviour and biology (Ratamäki 2013b); but hunting also does this. All of these issues are debated but not properly discussed by the different stakeholders.

Finally, the question: why? Why is the hunter's activity more important than Eero's activities? In Lefebvre's terms, why is this space as lived and perceived by hunters more legitimate than it is lived and perceived as a space for viewing and photographing? Why does Eero have to alter his ways of affecting the material/physical world when the hunting season starts? Is it because hunting is taken for granted, because it is considered almost a citizen right? Or is it because hunting serves a greater good for society in terms of game management? Or perhaps because Eero's business, at least as it stands now, involves fewer people and institutions than hunting? The second reason does not answer why the area around Eero's hides could not be restricted from hunting. However, the first and last reasons would.

\section{Looking for solutions}

Erä-Eero's business represents a new way of enjoying natural resources in rural Finland. It has faced some tension when coming across other activities that take place in the same area at the same time. These other activities have been practised in the area before and the stakeholders are not willing to change their practices because of this new phenomenon. Based on our analysis, a few openings to tackle this situation can be recognised.

Eero himself has identified the importance of co-operation with other actors in the region. It is easy to see how the other businesses related to tourism and also the municipality can benefit from this co-operation. It is more difficult to identify incentives for the parish and the state as land owners or the hunters. But let's try.

There is great potential to intensify nature tourism in Lieksa and thus support the region's economy. The more Eero builds up networks and social interaction with other stakeholders or vice versa in the region, the more entangled he will become with the practices, people and institutions. This, if the co-operation is successful, will enhance the collective acceptance of his business. In other words, Eero must become more integrated with the surroundings and draw the rhythms of different entrepreneurs closer to each other.

Developing co-operation between stakeholders would require a set of commonly-accepted rules and contracts or promises between two or more participants. The municipality or regional councils might be good facilitators, but on the other hand, so far Eero has managed to develop his business just by co-operating with other private stakeholders.

\section{Results - Saimaa ringed seal}

The interplay between stakeholders in the Saimaa ringed seal case is strongly dependent on the seals' annual rhythm. Researchers have to take into account the annual rhythm of the seals when designing the collection of data. The seals' rhythm also increasingly determines 
the fishers' practices in time and space, directly by the impact of the seal itself or indirectly due to fishing restrictions. Even though fishing is one part of the rural natural-resource-utilising lifemode, with a built-in idea of local management (water and land ownership), there has been strong willingness on behalf of the fishers to voluntary adjust their fishing, spatially and temporally. This may be explained by the fact that the seal itself is seen as an element in the life-mode based on "erä-culture". Fishers unanimously state that they have nothing against the seal - the resistance is targeted at fishing restrictions imposed by national authorities, which are not in line with the idea of local management. The mental idea of the seal is also perceived as positive in cultural representations like the children's seal opera or the ringed seal statue in the town of Savonlinna.

Temporal and spatial rhythms of the seal and the fisher determine the types and frequencies of interactions. The interactions are mutually beneficial and harmful between fishers and seals. Seals benefit but also suffer from fishing practices. Fishers may gain cultural values from the existence of seals, but the spatial expansion of springtime fishing restrictions has particularly aroused conflict.

The latest conflict was a result of new restrictions being enforced and the fishers' voluntary agreements are seen as insufficient in terms of conservation. Through negotiating the voluntary agreements, the fishers have had a chance to adjust their life-modes and rhythms to new situations. Instead, the restrictions imposed from above do not allow such an adaptation process.

This seal-fisheries controversy is one in a bundle of contradictions between land-owning inhabitants in remote rural areas and new postproductivist measures, such as nature conservation, in Finland. Those water owner fishers, who are activists in local fisheries management, have been the most critical towards increased top-down fishing restrictions. Moreover, a nature tourism entrepreneur has proposed that green city people are systematically endangering rural life and nature-based livelihoods, e.g. in the form of media shows demanding fishing restrictions (Laitinen, 2011). The Programme of the Finnish Government (2011) states that: "The protection of the Saimaa ringed seal will be improved by expanding the zone in which net fishing is prohibited according to what is appropriate to the survival of the species". Thus the expansion of the springtime fishing regulation can be expected to continue.

Biologists and the nature protection lobby, as well as administration, have played an important part in shaping the rhythms between seals and fishers. The nature protection organisations have successfully used mass media for the promotion of seal protection with a particular emphasis on expanding the fishing restrictions. The seal biologists are also oriented towards the mission of seal conservation. They are experts in the life-mode and rhythms of the seal, but not regarding the commercial and recreational fishers. At the same time, many of the fishers in the Saimaa region find the life-mode and intentions of the seal protection lobby hard to understand.

\section{Looking for solutions}

Mitigating the obstinate contradictions between fishing and the protection of the Saimaa ringed seal can be defined as a "wicked problem", typical in the sphere of fisheries governance (Jentoft and Chuenpagdee, 2009), as well as in wildlife (Leong et al, 2009) and equine (Andersson and Lehtola, 2011) issues. Wicked problems have no technical or right or wrong solution that can be determined scientifically. Instead, governance must rely on the collective judgment of the stakeholders involved in the process concerning what the problem is about and what the routes forward are. This necessitates understanding of the arrhythmias and life-modes involved.

There have been some attempts to reconcile the conflicts over the conservation of the Saimaa ringed seal. In the 1980s, voluntary agreements for fishing restrictions were signed by the local shareholder (water owner) associations and WWF (Etelä-Savon TE-keskus, 2008). The Ministry of Agriculture and Forestry offered financial compensation to these associations.

The commercial fishers were granted compensation for their seal protection-induced economic losses in 2010. A project for developing seal-safe commercial fishing gear was started. 
The working groups have also proposed that citizens' seal observations should be used in the monitoring of the ringed seal population. The practical means of utilising public seal observations is, however, unclear. People detect seals mostly during the open water seasons. The official monitoring of the seal population is based on annual collaborative counting of breeding lairs, which has to be done during a short spring period after the seal mother and pup have left the lair and before the melting of the snow and ice. In 2011 a total of 150 persons took part in this activity, most of whom were local volunteers (Metsähallitus, 2011). This process has also been criticised: the lair counters use snowmobiles and hydrocopters, which are thought to disturb the seals.

Despite attempts to mediate the conflict, it seems that the understanding of the other groups' life-modes and practical rhythms has not been notably increased. This may be because the discussion has not had such analytical tools. The process towards overcoming blindness between life-modes requires a comprehensive recognition of the need for collaborative and transparent goal definition, decision-making and a practical focus on overcoming the disadvantages of arrhythmias.

\section{Synthesis and conclusions}

Rhythmanalysis is a very revealing tool. It helps to parallel different practices which occur in space and time without giving priority to one over another. Our analysis has shown how photographing, hunting or fishing and conservation of the seal are practices that take place in the same physical space and sometimes temporally overlap. The power relations between these practices are not facts but socially constructed norms, ways of living and perceiving the space. These norms are utilised to justify the different practices and their importance. The origins of the social norms can be located in the different life-modes. The introduction of new practices, e.g. a new enterprise or conservation of an endangered species, creates arrhythmias to more traditional practices and they can be very resistant to change. This strong resistance can be understood (not to say legitimised) by the idea of a life-mode. A life-mode is expressed and regenerated by different practices, symbols and concepts in time and space. Some of these have longer timespans than others. Some are also more widely spread and shared than others.

The spatial and temporal rhythms carry and regenerate social meanings. Hunters' and fishers' rhythms are manifestations of cultural identities. Maintaining rhythms is to uphold life-modes and associated identities (Edensor, 2006). Asking people to change their rhythms is not a light request. Changing rhythms is to change one's life-mode, cultural identity and, in this case, understanding of the legitimate human-nature relation. Being a hunter or a fisher is about particular praxis attached to places and is generated through the established annual and daily rhythms in a given space. Over generations, these rhythms have been shaped in connection with the material dimension: a particular hunting or fishing activity is focused on those seasons when the availability of the particular game or fish species is at its highest. Withholding from these practices and breaking down the rhythms is to cease being a hunter or a fisher. Furthermore, this does not apply only to individuals but also to collectives and national identities. This explains why new postproductive measures incur such opposition. Developing nature conservation strategies which aim to rescue or maintain a sustainable rhythm of an endangered species, but do not encounter this opposition, is only a halfway strategy.

However, a rhythm as a concept has some potential as a practical mitigation tool in conflict situations. It draws attention to practices instead of values. In the case of the Saimaa ringed seal, for instance, close co-operation between fishers and seal biologists could integrate local and scientific knowledge about the seals' movements and thus support tailoring seal-safe fishing practices. In the case of Erä-Eero it seems that by interpreting the situation through rhythms, it is possible to draw some practical suggestions on how to avoid the arrhythmia; by separating the conflicting practices in space. However, as shown, neither the hunters nor the land owners have been willing to go along with such suggestions. Therefore, the rhythmanalysis reveals only potential suggestions and it should be used in combination with the concept of a life-mode. This brings forth the social norms behind the rhythms and opens up 
the question of legitimacy and justification of any given practice. Analysis of life-modes reveals the social orderings of the rhythms.

\section{References}

[1] Ahola, R. (2010). Fortum-katiskatempauksiin Saimaalla vuosina 2008 ja 2009 osallistuneiden kalastajien saimaannorpan suojelukulttuuri. [Master thesis]. Joensuu: ItäSuomen yliopisto.

[2] Andersson, K. \& Lehtola, M. (2011). Regulating the new equine industry in Finland. Wicked problems, governance models and gendered power structures. Sociologia Ruralis 51(4), 387-403. DOI: 10.1111/j.1467-9523.2011.00545.x.

[3] Auttila, M., Niemi, M. \& Kunnasranta, M. (2010). 'Tutkimus perustana norpan suojelulle', Suomen Kalastuslehti 7/2010, 12-14.

[4] Bærenholdt, J. O. (2009). Coping with mobility: Rethinking regional development in tourism on Lolland. Paper for Nordic Geographers' Meeting 8-11 June 2009, Turku. Available from http://rudar.ruc.dk//bitstream/1800/4217/2/Coping_with_Mobility.pdf [Retrieved 2 Nov 2012].

[5] Bisi, J., Kurki, S., Svensberg, M. \& Liukkonen, T. (2007). 'Human Dimensions of wolf (Canis lupus) conflicts in Finland', European Journal of Wildlife Research 53(4), 304-314. DOI: 10.1007/s10344-007-0092-4

[6] Bisi, J., Liukkonen, T., Pohja-Mykrä, M., Pohja-Mykrä, S. \& Kurki, S. (2010). 'The good bad wolf-wolf evaluation reveals the roots of the Finnish wolf conflict', European Journal of Wildlife Research, 56(5), 771-779. Doi: 10.1007/s10344-010-0374-0.

[7] Buller, H. J. (2004). 'Where the wild things are: the evolving iconography of rural fauna', Journal of Rural Studies 20(2), 131-141. Doi: 10.1016/j.jrurstud.2003.08.009.

[8] Edensor, T. (2006). 'Reconsidering National Temporalities: Institutional Times, Everyday Routines, Serial Spaces and Synchronicities', European Journal of Social Theory 9(4), 525545. Doi: 10.1177/1368431006071996.

[9] Edensor, T. (2010). 'Introduction: Thinking about Rhythm and Space' (pp. 1-20), In Edensor, T., ed., Geographies of Rhythm. Nature, Place, Mobilities and Bodies, Farnham: Ashgate.

[10] Eskelinen, P. (2009). Karhut elinkeinona - millaisia ovat katselupalveluja tarjoavat yritykset? Helsinki: Riista- ja kalatalous, Selvityksiä 15/2009.

[11] Etelä-Savon TE-keskus (2008). Saimaannorppa ja kalastus - työryhmän raportti [Working group report], Etelä-Savon TE-keskuksen raportteja 7/2008.

[12] Forsman, L., Wikman, M., Härkönen, S. \& Eskelinen, P. (2010). Riistatalouden vapaaehtoistyö, Helsinki: Riista- ja kalatalous, Selvityksiä 10/2010.

[13] Højrup, T. (2003). State, Culture and life-modes. The foundations of life-mode analysis, Aldershot: Ashgate.

[14] Ilvesviita, P. (2005). Paaluraudoista kotkansuojeluun - Suomalainen metsästyspolitiikka 1865-1993, [Finnish hunting policy between 1865-1993 - from ruthless elimination of predators to the protection of eagles]. Acta Universitatis Lapponiensis 93. Rovaniemi: University of Lapland.

[15] Jentoft, S. \& Chuenpagdee, R. (2009). 'Fisheries and coastal governance as a wicked problem', Marine Policy 33(4), 553-560. Doi: 10.1016/j.marpol.2008.12.002.

[16] Jones, O (2010). "The breath of the Moon': The Rhythmic and Affective Time-spaces of UK tides' (pp. 189-204). In Edensor, T., ed., Geographies of Rhythm. Nature, Place, Mobilities and Bodies, Farnham: Ashgate. 
[17] Karsikas, L. (2007). Metsästyksen ongelmapuhe Acta Universitatis Ouluensis. Series E. Scientiae Rerum Socialium.University of Oulu.

[18] Kolari, I., Hirvonen, E., Salmi, P. \& Salmi, J. (2011). 'Vapaa-ajankalastus saimaannorpan esiintymisalueella' [Reports 17/2011], Helsinki: Finnish Game and Fisheries Research Institute.

[19] Laitinen, J. (2011). 'Luontaiselinkeinot "cityvihreiden" puristuksessa', Itä-Savo Newspaper, 9 April 2011, p. 4. Letter to the editor.

[20] Lefebvre, H. (1991). The production of space. Oxford: Blackwell Publishing.

[21] Lefebvre, H. (2004). Rhythmanalysis. Space, time and everyday life, London/New York: Continuum.

[22] Leong, K., Decker, D. J., Lauber, T. B., Raik, D. B. \& Siemer, W. F. (2009). Overcoming jurisdictional boundaries through stakeholder engagement and collaborative governance: Lessons learned from white-tailed deer management in the U.S (pp. 221-247. In Andersson, K., Eklund, E., Lehtola, M. \& Salmi, P., eds., Beyond the rural-urban divide: Cross-continental perspectives on the differentiated countryside and its regulation. Research in rural sociology and development vol. 14. Emerald.

[23] Ministry of Agriculture and Forestry (2005). Management plan for the wolf population in Finland 11b/2005, Helsinki: Ministry of Agriculture and Forestry.

[24] Ministry of Agriculture and Forestry (2011). 'Valtioneuvosto hyväksyi kaksi asetusta saimaannorpan suojelun tehostamiseksi', Press release 6 April 2011. Available from: http://www.mmm.fi/fi/index/etusivu/tiedotteet/110406_saimaannorpan_suojelu.html, Retrieved at 19 Aug 2011].

[25] MEK, Matkailun edistämiskeskus (2008). Eläintenkatselu ja -valokuvaus matkailutuotteena. Helsinki: Matkailun edistämiskeskus.

[26] Metsähallitus (2009). The Saimaa ringed seal Phoca hispida saimensis. The most endangered seal in the world? Available from: http://www.metsa.fi/sivustot/metsa/en/NaturalHeritage/SpeciesandHabitats/ThreatededAni mals/Documents/Saimaaringedseal_English.pdf, [Retrieved 21 Jan 2013].

[27] Metsähallitus (2011). Saimaannorpan pesälaskennoissa todettiin 52 poikasta. Press release $26 \quad$ April 2011.2 Available from: http://www.metsa.fi/sivustot/metsa/fi/ajankohtaista/Tiedotearkisto/Tiedotteet2011/Sivut/Sai maannorpanpoikasia52.aspx, [Retrieved at 21 Jan 2013].

[28] Pohja-Mykrä, M. \& Kurki, S. (2009). Suurpetojen haaskaruokinnan yhteiskunnallisen kestävyyden haasteet. Seinäjoki: University of Helsinki, Ruralia-Institute.

[29] Finnish Government (2011). Programme of the Finnish Government, 22 June 2011. Available from: http://valtioneuvosto.fi/hallitus/hallitusohjelma/pdf/en334743.pdf, [Retrieved at 21 Jan 2013].

[30] Rannikko, P. (2008). 'Postproduktivismi metsässä' In Karjalainen, T. P., Luoma, P. \& Reinikainen, K., eds., Ympäristösosiologian virrat ja verkostot, Oulu: University of Oulu, Thule Institute.

[31] Ratamäki, O. (2013a). 'From Ecological Concerns toward Solving Societal Problems?: A case study of the Development of Finland's Wolf Policy', International Journal of Information Systems and Social Change 4(2), 42-58. Doi: 10.4018/jissc.2013040103.

[32] Ratamäki, O. (2013b). 'Ekosysteemipalvelu -käsite paikallisessa kontekstissa tapaustutkimus suurpetojen katselu- ja valokuvauspalveluista Lieksassa' TERRA 125(2), 57-70.

[33] Salmi, J., Salmi, P. \& Hirvonen, E. (2011). Ammattikalastus saimaannorppa -alueella [Reports 16/2011]. Helsinki: Finnish game and fisheries research institute. 
[34] Salmi, P. \& Ratamäki, O. (2011). 'Fishing culture, animal policy, and new governance: A case study of voluntary catch-and-release fishing in Finland' In Beard, T. D., Arlinghaus, R. \& Sutton S. G., eds., The angler in the environment: social, economic, biological, and ethical dimensions, Proceedings of the $5^{\text {th }}$ World Recreational Fishing Conference. American Fisheries Society, Bethesda, Maryland, USA. American Fisheries Society Symposium 75.

[35] Schmid, C. (2008). 'Henri Lefebvre's theory of the production of space: towards a threedimensional dialectic'(pp. 27-45). In Goonewardena, K., Kipfer, S., Milgrom, R. \& Schmid, C., eds., Space, Difference, Everyday Life. Reading Henri Lefebvre. New York: Routledge.

[36] Suonpää, J. (2002). Petokuvan raadollisuus. Luontokuvan yhteiskunnallisten merkitysten metsästys. Tampere: Vastapaino.

[37] Toivonen, A-L. (2009). Suomalainen metsästäjä. Riista- ja kalatalous, Selvityksiä 19/2009, Helsinki: Finnish Game and Fisheries Research Institute.

[38] Tovey, H. (2003). 'Theorising nature and society in sociology: The invisibility of animals', Sociologia Ruralis 43(3), 196-215. Doi: 10.1111/1467-9523.00241.

[39] Tonder, M. (2005). Anatomy of an environmental conflict - Case of the conservation of the Saimaa ringed seal, Joensuu: University of Joensuu.

[40] Tuomivaara, S. \& Purmonen, J. (1998). Ulos häkeistä! Kaksi näkökulmaa uuden eläinliikkeen sisältä Helsinki: Tammi. 